\title{
PENDEKATAN PEDOGEOMORFOLOGI DALAM PENELITIAN ARKEOLOGI DI GUNUNG LANANG DAN GUNUNG WINGKO (BANTUL)
}

\author{
Oleh: Sunarto*)
}

\section{PENGANTAR}

Secara umum, arkeologi mempunyai pengertian sebagai pengetahuan tentang sesuatu bangsa pada masa lampau berdasarkan pe ninggalan-peninggalan bangsa itu yang masih terdapat sampai dewa. sa ini (Ariyono Suyono, 1985). Benda-benda peninggalan masa lam pau sebagai artefak dapat menjadi petunjuk dalam penyelidikan arkeologi. Artefak dalam hal ini adalah benda-benda buatan manu sia, seperti tembikar, manik-manik, dan lain-lain. Secara tipologis artefak yang ditemukan itu mengikuti keadaan alam. Hal ini disebabkan oleh adanya pengaruh kuat dari lingkungan alam terhadap masyarakat penduduknya.

Apabila diperhatikan, keadaan alam itu mengikuti pola-pola alamiah tertentu, sehingga mempunyai bentuk khas yang lazim disebut sebagai bentuklahan (landform). Pengertian bentuklahan itu sendiri pada prinsıpnya adalah bagian dari permukaan bumi yang mempunyai karakteristik bentuk yang khas, akibat dari kuatnya pengaruh proses dan susunan batuan tertentu selama perkembangannya. Karena bentuk permukaan bumi itu khas dengan proses tertentu dan susunan batuan tertentu pula, maka selama perkem. bangan bentuklahan itu terjadi, manusia yang hidup pada bentuklahan itu akan terpengaruh pula. Di bawah pengaruh bentuklahan, manusia hidup dan berkehidupan sosial-budaya, yang akhirnya meninggalkan berbagai artefak yang kini telah terkubur di dalam tanah.

Untuk dapat mengungkap ruang, waktu, dan keadaan kehidupan masa lampau berdasarkan artefak yang ditemukan, akan lebih efektif dan efisien apabila didukung dengan pengetahuan tentang

ๆ) Jurusan Geomorfologi. Fakultas Geografi UGM. 
bentuklahan dan tanah. Oleh karenanya, survei arkeologi ini dilakukan dengan pendekatan pedogeomorfologi. Menurut Gerrard (1981), pedogeomorfologi merupakan suatu perpaduan ilmu antara pedologi (ilmu tentang tanah) dan geomorfologi (ilmu tentang bentuk muka bumi/bentuklahan), yang muncul sebagai sintesis baru untuk membantu memahami lingkungan fisik yang menjadi fokus utamanya dan juga fungsi tanah.

Pendekatan pedogeomorfologi dalam survei arkeologi akan memudahkan pembedaan antara material geologis (batuan) dengan material pedologis (tanah), baik itu yang masih tampak di permukaan bumi maupun yang sudah terkubur. Kehidupan manusia berlangsung di atas tanah, karena tanah dapat menumbuhkan tanaman yang dibutuhkan manusia. Akibatnya, artefak banyak dijumpai di dalam tanah. Lain halnya dengan batuan, dalam hal ini adalah pasir pantai, pada bentuklahan tertentu dapat digunakan untuk mengetahui lingkungan purba berdasarkan analisis ukuran butir pasir. Digunakannya analisis ukuran butir, sebab Gunung Wingko maupun Gunung Lanang bermaterial pasir pantai.

Permasalahan yang timbul di daerah survei ini meliputi tiga hal yang harus diselesaikan secara pedogeomorfologis, yaitu: (1) Apakah rangkaian Gunung Wingko itu berasal dari lapisan gumuk pasir (sand dune), tanggul alam (natural levee), atau beting gisik (beach ridge)?; (2) Apakah Gunung Lanang itu termasuk rangkaian Gunung Wingko, rangkaian beting gisik Selatan, atau berdiri sendiri?; (3) Bagaimana sebaran (distribution) arang dan abu pada beberapa test pit di Gunung Lanang?

\section{DESKRIPSI LINGKUNGAN FISIK}

Gunung Lanang dan Gunung Wingko terletak di antara 759'LS dan $8^{\circ} 0^{\prime} \mathrm{LS}$ serta di antara $110^{\circ} 16^{\prime} \mathrm{BT}$ dan $110^{\circ} 18^{\prime} \mathrm{BT}$. Daerah ini terletak kurang-lebih $23 \mathrm{~km}$ ke arah selatan kota Yogyakarta, yaitu di daerah pesisir Selatan. Secara geologis, daerah ini terdiri atas dua formasi batuan, yaitu formasi batuan segar (pada gisik dan gumuk pasir pantai) dan formasi batuan Holosen (pada aluvium dari sungai). Kondisi iklimnya mempunyai curah hujan tahunan rata-rata $1.648 \mathrm{~mm}$, kisaran suhu bulanannya $26,2^{\circ}-26,3^{\circ} \mathrm{C}$, dengan kecepatan angin berkisar 1,4-2,4 m/detik (Sunarto, 1982; Speelman, 1979). 
Berdasarkan genesisnya, daerah survei ini terbentuk oleh tiga proses alami, yaitu proses laut, proses fluvial (aliran air), dan proses angin. Ketiga proses alami itu masing-masing membentuk berbagai bentuklahan. Klasifikasi bentuklahan secara geomorfologis yang dihasilkan oleh ketiga proses alami tersebut adalah seperti berikut ini:

A. Bentuklahan dari hasil proses laut: beting-gisik dewasa (mature beach ridge), beting-gisik muda (younger beach ridge), betinggisik segar (recent beach ridge), cekungan antar beting-gisik (swale), dan bura (spit).

B. Bentuklahan dari hasil proses fluvial: dataran banjir (flood plain), tanggul alam (natural levee), rawa terbendung (backswamp), bekas sungai, gosong sungai (river bar), dataran aluvial (alluvial plain), dan igir aluvial (alluvial ridge).

C. Bentuklahan dari hasil proses angin: gumuk pasir (sand dune).

Jenis-jenis tanah yang ada di daerah survei adalah Regosol dan Tanah Aluvial. Persebaran kedua jenis tanah tersebut bersesuaian dengan formasi geologis daerah ini. Kondisi hidrologis permukaan lahan menunjukkan bahwa tidak terjadi aliran permukaan karena topografinya landai hingga cekung dan bermaterial pasir yang dominan. Air tanah yang terkandung di bawah secara kuantitatif berjumlah besar karena daerah itu mempunyai akuiver (lapisan batuan pembawa air) yang baik. Kondisi oseanografis daerah survei ini menunjukkan bahwa tinggi empasan ombak berkisar $2-3 \mathrm{~m}$, pasangsurutnya berkisar $1-1,5 \mathrm{~m}$, dan kecepatan arusnya lebih dari $1,2 \mathrm{~m} /$ detik (Sunarto, 1982; Sbdul Sobur, 1982; Suyono dan Goffau, 1981).

\section{TUJUAN}

Tujuan survei arkeologi dengan pendekatan pedogeomorfologi meliputi hal-hal seperti berikut ini:

1. Mengadakan penyidikan material penyusun, baik pada betinggisik utara maupun beting-gisik selatan.

2. Membuat penampang lapisan dari hasil penyidikan pada tujuan pertama. 
3. Memberikan ketentuan bahwa secara fisik, Gunung Lanang itu termasuk salah satu dari kedua beting-gisik, ataupun memberikan ketentuan bahwa Gunung Lanang itu berdiri sendiri.

4. Mengadakan pengamatan material penyusun pada setiap test pit di Gunung Lanang untuk memperoleh sebaran arang dan abu.

\section{DATA DAN METODE}

Data yang dikumpulkan meliputi data tanah (warna, tebal, tekstur), dan data sedimen (rata-rata, pemilahan, kemencengan, dan kurtosis ukuran butir). Di samping itu, data kecepatan angin dan tinggi empasan amat diperlukan untuk analisis proses geomorfik.

Metode penelitian yang digunakan adalah metode survei. Sedangkan penentuan lokasi pengamatan dan pengambilan sampel berdasarkan metode morfogeografi. Pengertian metode morfogeografi ini menurut Bashenina (di dalam : Demek dan Embleton, Eds., 1978) yakni metode penelitian geomorfologis untuk mengkaji hubungan antara relief dengan unsur-unsur lingkungan geografis lainnya. Lokasi sampel dapat dilihat pada Peta Kontur Kawasan Gunung Lanang.

Alat-alat yang digunakan dalam survei ini meliputi: seperangkat alat uji tanah lapangan (soil test kit), lensa pembesar dengan pembesaran 20 kali, buku warna tanah Munsell, cangkul, sekop, pisau, peia kerja, dan foto-udara pankromatik hitam-putih berskala $1: 10.000$.

\section{HASIL DAN PERBINCANGAN}

\section{A Penampang-bujur Beting-gisik Gunung Wingko}

Untuk mengetahui penampang-bujur beting-gisik di rangkaian Gunung Wingko, dibuat serangkaian profil tanah dari barat (desa Karanganyar) hingga timur (desa Gegunung). Jumlah titik sampel profil tanah sebanyak enam buah. Profil tanah yang disidik terletak merata baik pada igir, lereng, maupun lembah.

Hasil penyidikan di setiap profil tanah menunjukkan bahwa di seluruh titik sampel profil tanah dapat dibedakan menjadi dua lapis- 
an utama, yakni lapisan atas dan lapisan bawah. Lapisan atas warnanya kecoklatan, teksturnya lebih halus, dan ketebalannya bervariasi sesuai dengan topografinya. Pada igir, tebal lapisan atas lebih tipis dari pada lapisan atas yang terdapat di lembah. Hal ini menunjukkan telah terjadi erosi pada igir, yang sebagian besar materialnya terpendam di lembah-lembahnya. Sedangkan penyidikan pada lapisan bawah diperoleh hasil bahwa warna tanahnya kelam/kelabuan, teksturnya lebih kasar, dan ketebalannya besar.

Analisis ukuran butir menunjukkan bahwa beting-gisik di rangkaian Gunung Wingko mempunyai parameter seperti berikut ini.

Lapisan atas:

- Rata-rata (mean) ukuran butir pasirnya termasuk pasir sedang hingga halus,

- Harkat pemilihan (sorting) dari sedang hingga amat jelek,

- Kemencengan (skewness) dari halus hingga sangat halus,

- dan Kurtosis kebanyakan termasuk very leptokurtic.

Lapisan bawah:

- Rata-ratanya termasuk pasir sedang,

- Harkat pemilihannya semua termasuk agak baik.

- Kemencengannya dari halus hingga sangat halus, dan

- Kurtosisnya kebanyakan termasuk mesokurtic.

Berdasarkan parameter tersebut dapat dievaluasi bahwa lapisan atas terjadi dari material pasir yang diendapkan oleh aktifitas angin yang kekuatannya, arah datangnya, maupun frekuensi datangnya berubah-ubah. Hal ini ditunjukkan oleh rata-rata ukuran butir pasirnya sedang hingga halus dan harkat pemilihannya sedang hingga amat jelek. Kondisi angin yang berubah-ubah ini menyebabkan pula harkat kurtosisnya menjadi very leptokurtic atau grafiknya amat runcing, hal ini menunjukkan bahwa proses pengendapannya tidak teratur.

Lain halnya dengan lapisan bawah, ditinjau dari harkat pemilihannya yang agak baik, berarti kekuatan, arah, dan frekuensi tenaga pengendapannya lebih teratur (harmonis). Tenaga pengendapan yang harmonis ini adalah tenaga ombak. Parameter pendukung lainnyaa adalah kemencengan yang simetris dan kurtosisnya berbentuk mesokurtic. Kedua parameter tersebut dapat menunjukkan proses pengendapan yang agak teratur. 
Dari kenyataan tersebut dapat ditentukan bahwa lapisan atas terjadi dari endapan pasir oleh tenaga angin (sand dune) dan lapisan bawah terjadi dari endapan pasir oleh tenaga ombak yang membentuk beting-gisik (beach ridge). Untuk lebih menjelaskan di bawah ini digambarkan profil tanah dari Gunung Wingko.

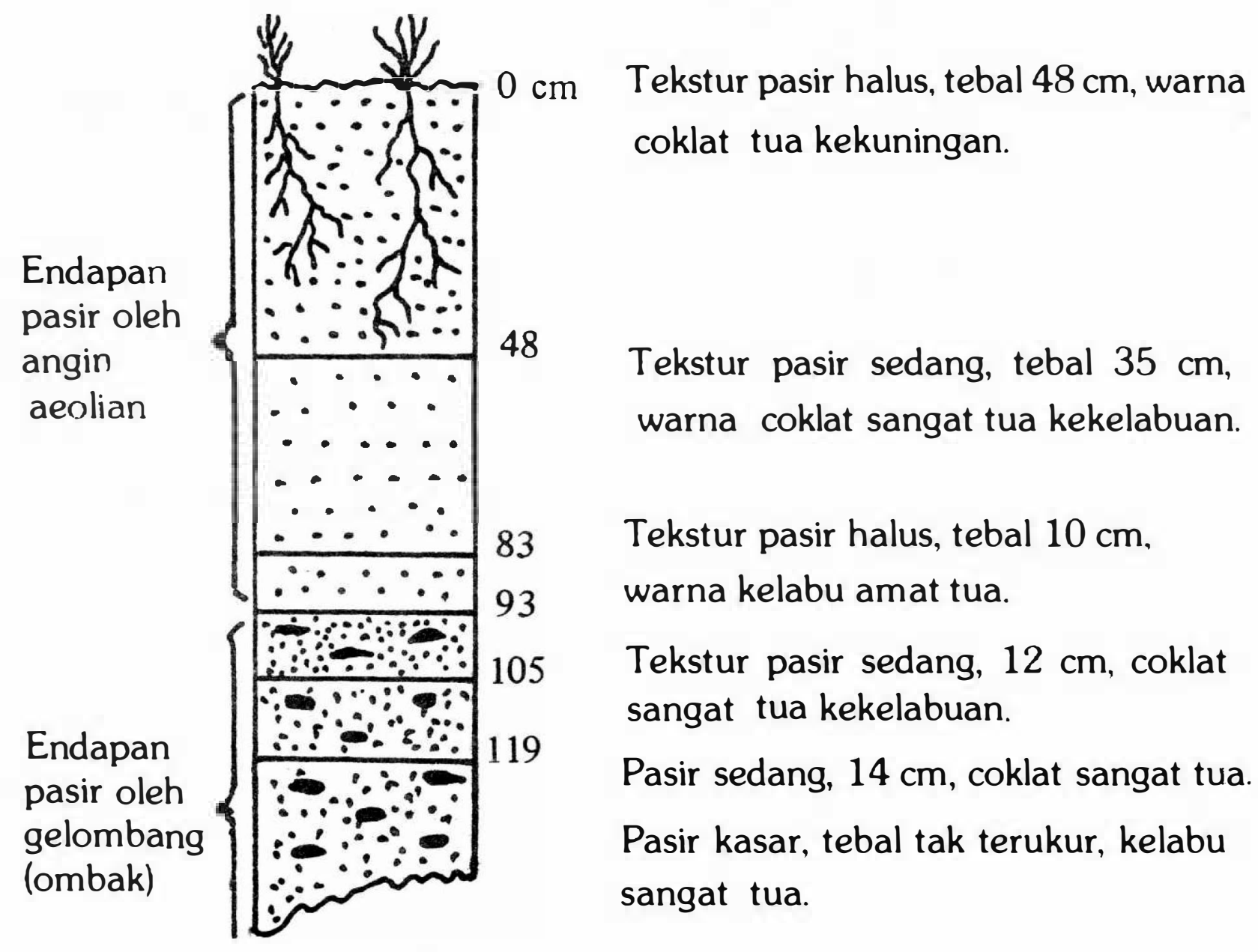

Gb.1: Profil Tanah di Gunung Wingko.

Di Gunung Wingko ini banyak dijumpai kereweng di dalam lapisan bawah, yaitu di lapisan pasir beting-gisik. Hal ini memberi informasi bahwa kegiatan purba terjadi pada masa beting-gisik itu masih dalam stadium segar (recent). Pengamatan mikro memperkuat keadaan ini dengan hasil yaitu tidak dijumpainya material terlapuk, akan tetapi masih dalam keadaan segar. Jika kegiatan purba itu terdapat pada beting gisik segar, maka permukiman mereka tidak menetap di beting-gisik itu, tetapi mereka menetap di luar betinggisik. Kegiatan mereka pada beting-gisik itu bersifat temporal. 


\section{B. Penampang-bujur Beting-gisik Gunung Lanang}

Seperti halnya penampang-bujur beting-gisik Gunung Wingko, pada penampang-bujur beting-gisik Gunung Lanang ini dibuat pula serangkaian profil tanah dari barat (Samas) hingga timur (Gunung Lanang). Jumlah profil tanah yang dibuat sebanyak empat titik pengamatan. Penentuan lokasi titik pengamatan juga dilakukan dengan metode morfogeografi.

Hasil yang diperoleh dari pengamatan profil tanah, yang meliputi sifat-sifat tekstur, warna, dan tebal lapisan tanah, ditunjukkan dengan penampang tegak seperti gambar di bawah ini.

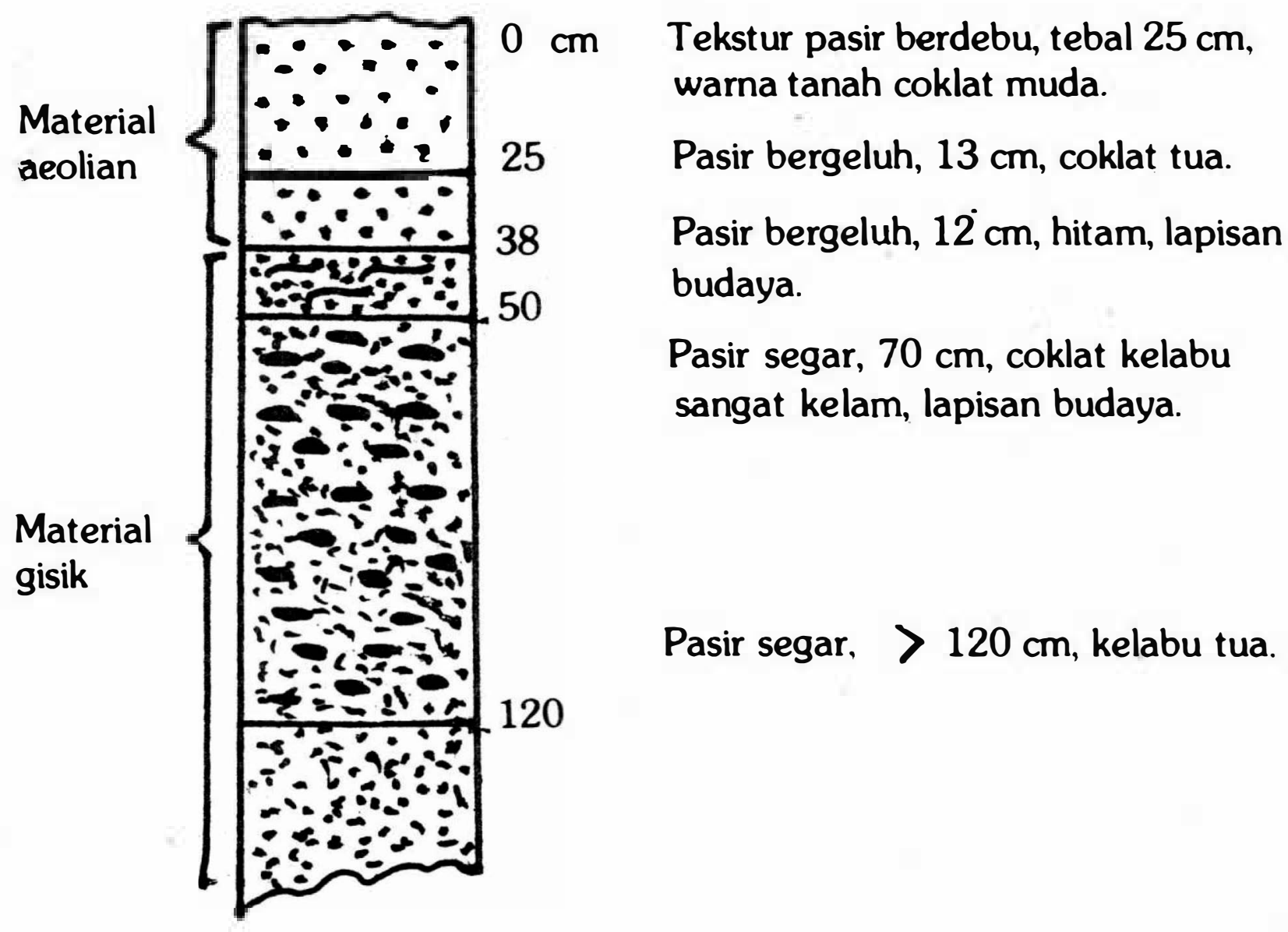

Gb. 2: Profil Tanah di Gunung Lanang. 
Berdasarkan penyidikan profil tanah baik di Gunung Lanang maupun di ketiga profil tanah lainnya, tampak jelas bahwa keempat profil tanah tersebut masih dalam satu rangkaian. Hal ini ditunjuk. kan oleh keseragaman lapisan. Ditinjau dari teksturnya, material pasir di Gunung Lanang dan ketiga profil tanah lainnya menunjukkan se. makin ke bawah semakin kasar. Di samping itu, warna tanahnya semakin ke bawah semakin kelam. Rata-rata pada kedalaman $0-38 \mathrm{~cm}$ berwarna kecoklatan, sedangkan pada kedalaman lebih dari $38 \mathrm{~cm}$ berwarna kelabu kelam. Dari kedua sifat tanah itu dapat diketahui bahwa rangkaian beting-gisik Gunung Lanang terdiri atas dua lapisan, yakni lapisan atas dan lapisan bawah. Berdasarkan kedua sifat tanah tersebut dapat pula diketahui bahwa lapisan atas itu merupakan material endapan pasir oleh tenaga angin (material aeolian), sedangkan lapisan bawahnya merupakan material gisik yang terjadi dari aktivitas gelombang laut.

Terpisahnya Gunung Lanang dari rangkaian beting-gisik, disebabkan karena adanya pemotongan oleh sungai terhadap beting-gisik. Sungai purba yang memotong beting-gisik itu menerobos di sebelah barat Gunung Lanang, sekarang ini yang tarnpak hanyalah lembah yang digunakan sebagai sawah. Walaupun pada saat ini Gunung Lanang merupakan bukit pasir yang tampaknya berdiri sendiri, namun jika ditinjau genesisnya Gunung Lanang itu merupakan satu rangkaian dengan beting-gisik di sebelah baratnya.

\section{Pembuktian Gunung Lanang Termasuk Beting-gisik Muda}

Berdasarkan peta satuan bentuklahan serta pengamatan dan penyidikan tanah, dapatlah ditentukan bahwa Gunung Lanang itu termasuk beting-gisik muda (BRy). Hal ini dapat diperikan seperti berikut ini.

Dari hasil interpretasi foto-udara pankromatik hitam-putih skala 1 : 10.000 dapat diketahui bahwa Gunung Lanang merupakan bukit terpencil. Bukit ini terpisah dari rangkaian beting-gisik di sebelah baratnya oleh adanya sungai purba. Sungai ini berasal dari arah timur, yang kemungkinan besar adalah sungai Winongo. Sungai ini terletak di sebelah utara Gunung Lanang dan mengalir ke arah barat. Karena semakin ke arah barat ketinggiannya semakin naik (lihat peta kontur), maka aliran air dari sungai ini tidak dapat melaju, 
akibatnya aliran air itu menerobos beting-gisik di sebelah selatannya Semakin lama terobosan itu semakin melebar dan menyebabkan terpotongnya beting-gisik itu. Beting-gisik yang terpotong itu dikenal dengan Gunung Lanang, sebagai bukit terpencil.

Sungai yang memotong beting-gisik itu berkelok dan bergabung dengan muara sungai Opak. Bekas-bekas saluran sungai ini tampak jelas dari foto-udara dengan memperhatikan unsur-unsur interpretasi. yaitu:

- Tekstur pada foto-udara yang tampak halus,

- Rona kelam karena perbedaan kelembaban tanah yang lebih tinggi daripada daerah sekitarnya,

- Pola berkelok dan bermuara, yang menunjukkan pola saluran sungai, dan

- Terletak di dataran banjir dan berawal dari tepi tanggul alam.

Di samping pembuktian dari foto-udara, Gunung Lanang sebagai rangkaian beting-gesik muda juga dibuktikan dengan pengamatan materialnya. Dari penyidikan profil tanah dan pengamatan material sedimen secara mikro diperoleh hasil bahwa material di Gunung Lanang itu sejenis dengan material sedimen yang ada di daerah perbatasan Tirtohargo dan di Desa Bugel Waru. Dengan demikian dapat ditentukan bahwa Gunung Lanang itu masih satu rangkaian dengan beting-gisik muda di sebelah baratnya. Gunung Lanang merupakan bukit terpencil karena adanya pemotongan sungai dari Kali Winongo.

\section{Pusat Kegiatan Purba di Gunung Lanang}

Teknik untuk menentukan letak pusat kegiatan purba yang ada di Gunung Lanang adalah dengan mengamati material secara mikro. dengan material indikator berupa arang dan abu yang tercampur dalam material pasir. Dasar pemikirannya adalah dari dugaan bahwa Gunung Lanang ini merupakan tempat kegiatanritual yang menggu. nakan gerabah dan perapian. Sisa-sisa perapian akan meninggalkan arang dan abu pada lahan yang digunakan untuk upacara ritual itu. Untuk menentukan letak pusat kegiatannya dapat diketahui dengan sebaran dan jumlah relatif arang pada masing-masing kotak di Gunung Lanang itu. 
Lapisan yang diamati secara mikro adalah pada lapisan kedua dan lapisan keempat. Kedua lapisan itu diambil karena lapisan kedua terletak di atas lapisan budaya (cultural layer) dan lapisan keempat ada di dalam lapisan budaya. Lapisan keempat itulah yang banyak mengandung banyak kereweng. Dari hasil pengamatan diperoleh kenyataan bahwa di lapisan kedua tidak dijumpai arang ataupun abu. Arang dan abu hanya ditemukan di lapisan keempat.

Dengan kenyataan tersebut dapat dievaluasi bahwa kegiatan purba benar-benar tejadi pada masa beting-gisik itu masih pada stadium muda (segar), sebab sebaran kereweng, arang, dan abu hanya ditemukan pada lapisan keempat yang tersusun dari material gisik. Akan tetapi setelah aktifnya proses angin, kegiatan purba itu tampaknya berakhir atau berpindah tempat. Hal ini terbukti tidak ditemukannya kereweng, arang, maupun abu di lapisan kedua.

\section{E. Temuan Fragipan di Gunung Lanang}

Pada ekskavasi di Gunung Lanang ditemukan dua jalur kenampakan membatu yang sejajar. Kedua jalur itu tersusun dari material pasir gisik yang mengeras. Secara mikro tampak bahwa susunan butirnya saling berimpitan dan teratur. Hal ini menunjukkan adanya tekanan dari atas oleh suatu beban yang tidak begitu berat, karena ketebalannya hanya $2-4 \mathrm{~cm}$. Pengerasan itu selain disebabkan oleh tekanan yang menyebabkan kompaksi, juga terjadi sementasi dengan perekat berwarna kecoklatan. Bahan semen itu berasal dari hasil proses oksidasi dan reduksi pada pasir besi. Kenampakan kedua jalur yang mengeras akibat kompaksi dan sementasi itu biasa dikenal sebagai fragipan. Kenampakan mikro fragipan itu digambarkan seperti berikut ini.

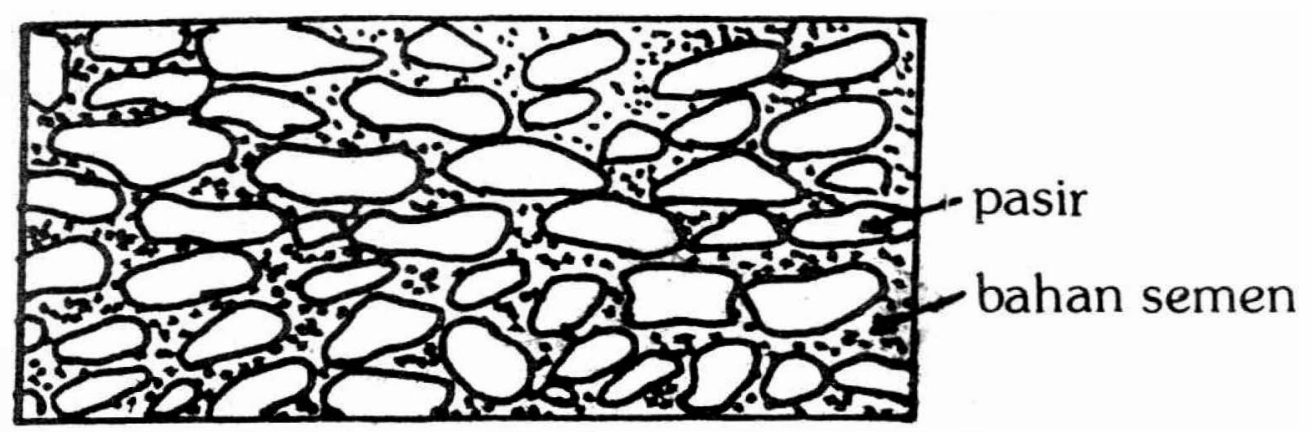

Gb. 3: Kenampakan mikro fragipan. 


\section{KESIMPULAN}

Kegiatan purba terjadi pada masa beting-gisik di pesisir Selatan Yogyakarta ini dalam stadium segar (recent). Karena kuatnya tindak. an angin, hal ini menyebabkan kegiatan purba itu berpindah tempat. Hal ini ditunjukkan dengan banyaknya kereweng ditemukan dalam material gisik, sedangkan di dalam material yang diendapkan angin tidak pernah ditemukan.

Berdasarkan hasil interpretasi bentuklahan, penyidikan profil tanah, dan pengamatan mikro sedimen, maka dapat ditentukan bahwa Gunung Lanang itu adalah beting-gisik yang masih merupakan satu rangkaian dengan beting-gisik muda di sebelah baratnya. Gunung Lanang merupakan bukit terpencil akibat pemotongan betinggisik muda oleh sungai. Sungai yang memotong beting-gisik itu sekarang sudah tidak tampak lagi, tetapi bekas-bekasnya masih dapat diidentifikasi dari foto-udara.

\section{UCAPAN TERIMA KASIH}

Survai arkeologi ini tidak akan dapat penulis laksanakan jika tidak mendapat bimbingan dari Bapak Drs. Gunadi. Oleh karena itu, dalam kesempatan ini penulis mengucapkan banyak terima kasih kepada Bapak Drs. Gunadi dan staf dari Balai Arkeologi Yogyakarta. 


\section{DAFTAR PUSTAKA}

ABDUL SOBUR AHMADSARIDO. 1982. Kondisi Geomorfologi Daerah Pantai dan Implikasinya terhadap Pengelolaan Lingkungan Fisik Daerah Pantai,

Disertasi Doktor. Universitas Gadjah Mada, Yogyakarta.

ARIYONO SUYONO. 1985. Kamus Antropologi. Akademika Pressindo c.v., Jakarta.

DEMEK J. dan C. EMBLETON. Eds. 1978, Guide to Medium-Scale Geomorphological Mapping. E. Schweizerbartsche Verlagsbuchandlung. Stuttgart.

GERRARD, A.J., 1981. Soils and Landforms. An Integration of Geomorphology and Pedology, George Allen \& Unwin, London.

SPEELMAN, H., 1979, Geology. Hydrogeology and Engineering Geological Features of the Serayu River Basin. Central Java, Indonesia, Disertasi Doktor, Vrije Universiteit Te Amsterdam, Amsterdam.

SUNARTO. 1982. Analisa Pembentukan Tanah pada Dataran Aluvial Pantai antara Sungai Opak dan Sungai Progo dengan Pendekatan Makro dan Mikromorfologi Tanah. Skripsi Sarjana, Fakultas Geografi UGM. Yogyakarta.

SUYONO dan A. DE GOFFAU, 1981. Geology and Hydrology of the Coastal Plain of the South Kedu Area (Central Java, Indonesia), Fakultas Geografi UGM. Yogyakarta. 